\title{
統合型降雨流出・洪水汇濫モデルによる佐用町 洪水災害分析と経済被害推定
}

\author{
DEVELOPMENT OF AN INTEGRATED MODEL FOR RAINFALL-RUNOFF/FLOOD \\ INUNDATION SIMULATION AND ECONOMIC LOSS ESTIMATNION FOCUSING ON \\ SAYO TOWN, HYOGO, JAPAN
}

\author{
小林健一郎 1 ・寶 馨 2 ・奥勇一郎3 \\ Kenichiro KOBAYASHI, Kaoru TAKARA and Yuichiro OKU \\ ${ }^{1}$ 正会員 Dr.-Ing., 博 (工) 京都大学特定准教授 学際融合教育研究推進センター \\ 極端気象適応社会教育ユニット（干611-0011 京都府宇治市五ヶ庄） \\ 2フェロー 工博 京都大学教授 防災研究所（产611-0011 京都府宇治市五ヶ庄） \\ 3非会員 博 (理) 京都大学特任助教 防災研究所（广611-0011 京都府宇治市五ヶ庄）
}

\begin{abstract}
This paper deals with the development of an integrated model for rainfall-runoff/flood inundation simulation and economic loss estimation, especially focusing on Sayo Town, Hyogo Prefecture, Japan where there was a severe flood disaster due to a heavy rainfall event on 9-10 August 2009. Firstly, the rainfall over the Sayogawa river catchment at the time is analyzed by using the composite radar and Radar-AMeDAS reanalysis data by the Japan Meteorological Agency in addition to the ground observation data. Second, the rainfall-runoff and flood inundation processes are simulated using the integrated model with the Radar-AMeDAS reanalysis data. The simulated inundation area shows the good agreement with the inundation record. Then, the economic loss estimation based on the simulated inundation area and depth is carried out and compared with the prospected value reported by the municipal government. The house/building economic loss estimated is 20.4 billion Japanese Yen, which agrees well with the reported value 18.5 billion Japanese Yen.
\end{abstract}

Key Words: integrated model, economic loss estimation, composite radar, Radar-AMeDAS, Sayo town

\section{1.はじめに}

2009年8月9日から10日にかけて台風9号による大雨に より兵庫県佐用町に甚大な洪水被害がもたらされた. 台風第 9 号災害検証報告書 ${ }^{11}$ によると2010年3月末日の集 計では, 佐用町で死者18名, 行方不明者2名, 負傷者1 名の人的被害が，また全壊家屋139，大規模半壊269, 半壊483, 床上浸水 157 , 床下浸水742など合計1789戸の 家屋被害が生じたと報告されている。また同報告書に よると農作物被害は被害面積が549.4ha，被害額総計が2 億456万円とある. 他方, 2009年12月1日時点で, 見込 みの住宅総被害額は185億円と試算されている2).

佐用町豪雨災害についての研究はこれまで例えば宇 野ら ${ }^{34}$ により実施されている。 これらの研究は久崎地 区の氾濫現象及び同地の水害時のソフト対策に焦点を 絞ったものである. 他方, 本稿では佐用川流域全体を 対象とした研究を実施した。具体的には本稿ではまず
流域全体を対象に佐用町豪雨災害における支派川の河 道流量と外水・内水汇濫浸水深をシミュレーションす るモデルを構築する. 次に, 汇濫浸水深に基づいて住 宅・作物被害額を推定し, 佐用町, 兵庫県により推定 された実態経済被害と比較することにより経済被害推 定モデルの精度の検証を試みる，これにより，洪水八 ザードのシミュレーション精度を高める事に加え, 流 域の洪水による経済リスクを事前に推定する手法の高 度化を図る。ここでは洪水浸水深の再現のために特に 佐用川流域全体を対象とした統合型の降雨流出・洪水 氾濫同時追跡シミュレーションモデルを構築した。 な お，以下に記述する統合型の降雨流出・洪水汇濫シ ミュレーションモデルを構築する理由として, 今回の 佐用町豪雨災害では，洪水流が河道から溢水しつつ流 下したという点がある. 一般的な物理法則に基づく分 布型の降雨流出モデルは斜面から河道への一方向の水 の移動を考えて, 河道から堤内地一の溢水については 考慮していないことが多い事から，今回この手法を採 

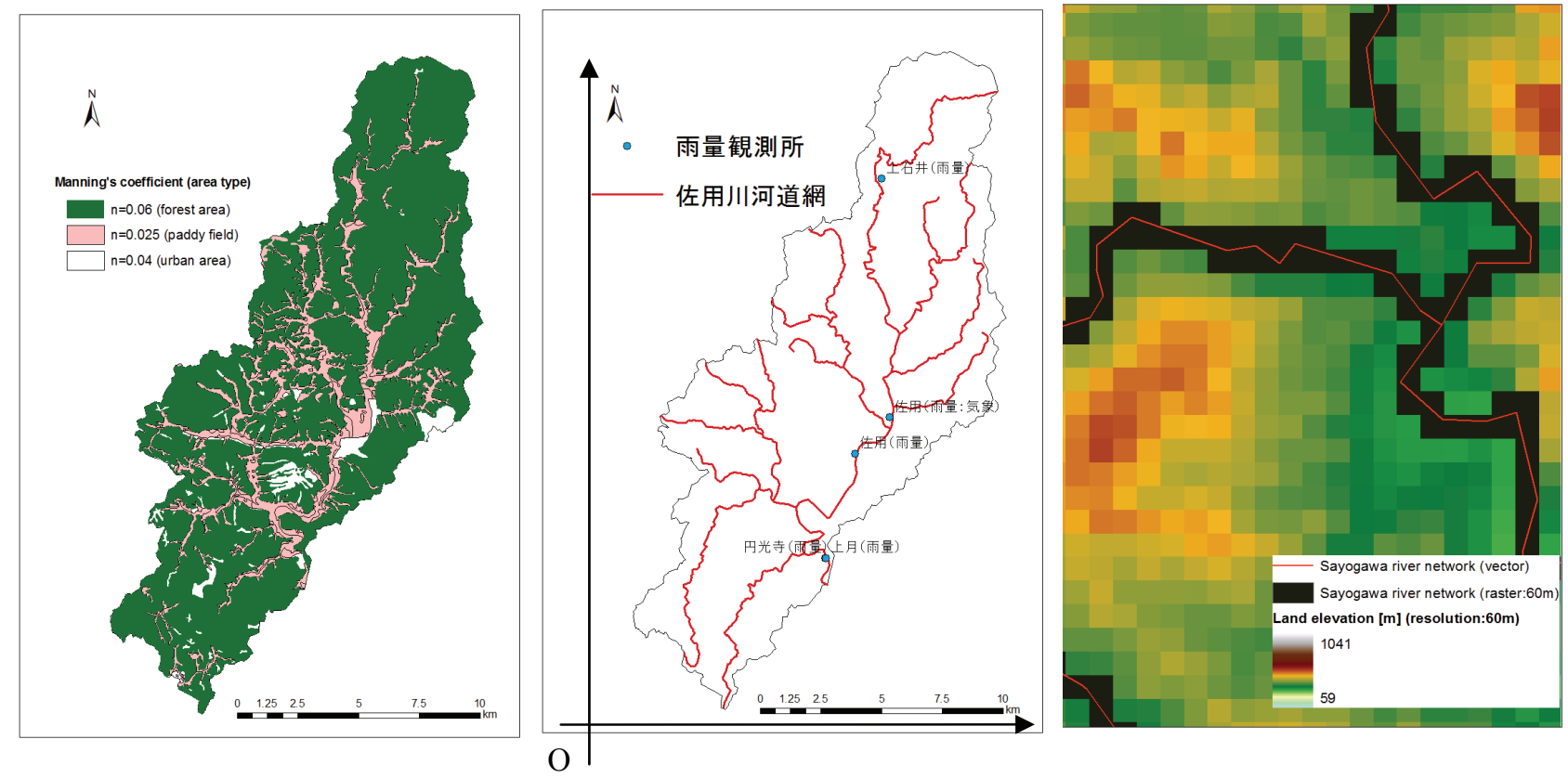

図-1 佐用川流域概要及び統合型降雨流出・洪水汇濫モデル概念図

用した。この点については実績のある汇濫原を考慮し た一次元解析法を採用寸ることも考えられるが，本稿 のように流域規模で一括的にデータプロセスを実施す ると，事前に汇濫原の範囲を特定する必要がないとい う利点がある. 他方, 流域全体に対する各種データ蓄 積量は洪水対策上の主要地点のそれよりも少ないこと が難点となるが，昨今，流域治水や支流水位の観測の 重要性などが指摘されていることなども考えて，本稿 のモデルは観測網の更なる整備など将来的な展開を視 野に入れて，この方式を採用した.

また，降雨による内水汇濫を考慮する際に，河道だ けでなく山腹斜面から平地に流れ出す水量を推定寸る 必要がある. 本稿の手法によれば山地と平地が統合さ れているので，この水量を推定することも可能である. 本稿の手法は分布型降雨流出モデルにより河道流量を 推定し, それを境界条件として洪水氾濫解析を実施す る手法と比べると, 流域内の流出・氾濫プロセスを一 体的に取り扱えるという利点がある. 他方，この統合 型手法では計算負荷は増加するが，特に一出水を対象 とする場合は統合型手法の利点は多いと考える.

\section{2. 佐用町の概要}

佐用町は兵庫県西部の千種川流域内部に位置し，居 住人口は平成 22 年 3 月末日で20166人，世帯数は7203戸 である. 本稿では被害の多かった円光寺地点（図-1） より上流の佐用川流域を対象とする（流域面積 $191 \mathrm{~m}^{2}$ ）。

図-1左に国土数值情報) より取得した森林・田畑・都 市域の分布図を掲載する。これによると森林面積は $151 \mathrm{~km}^{2}$ ，田畑面積は $37 \mathrm{~km}^{2}$ となった。 図-1中央の赤線は
河道網で，この図には雨量観測所の位置も示している.

\section{3. 統合型降雨流出・洪水氾濫追跡モデル}

本稿では図-1中央の河道網の流れは一次元不定流解 析により追跡し，流域の斜面や市街地の流れ（以後堤 内地流と呼ぶ）は二次元浅水流モデルにより追跡する.

一次元不定流、二次元洪水解析の基礎方程式、数值 計算手法は寸でに実績がある井上ら ${ }^{6)}$, 川池ら ${ }^{7)}$ の手法 を採用した。本稿のモデルはこれらの基礎方程式を流 域全体に拡張した点に特徵がある。流域への拡張は Kinematic wave法に基づく分布型降雨流出モデルに関す る研究も参考にした（例えば市川ら ${ }^{8)}$ )。図-1右に正 方形セルで表現した $60 \mathrm{~m}$ 解像度の標高データ, 国土数值 情報)から取得したベクトル型河道網データ，及びこれ をGISにより一次元ラスター化した $60 \mathrm{~m}$ 解像度の河道網 を示す。

堤内地計算の 2 次元座標系は図-1中央のように左下 の1地点を節点原点 $(i, j)=(0,0)$ とし，右及び上に $60 \mathrm{~m}$ 移 動するごとに節点番号が1ずつ増えることとした．節点 (i, j) ( $i=0, . .254, j=0, . .450)$ は常に図-1右のセルの中心に 位置し, 各節点に標高, 粗度係数などを割り当てる.

1 次元不定流計算はベクトル型の河道網データ（図1右赤線）をGISの機能を利用してラスター化した河道 網データを用いて実施する（図-1右黒色セル）。この 設定では河道流は上下左右方向にジグザグに流れると し，斜め方向には流れない，つまり河道流計算は常に1 次元で実施され解像度は常に $60 \mathrm{~m}$ である. 2次元浅水流 方程式により計算された堤内地流が節点 $(i, j)$ に到達す ると，その位置で結節された一次元不定流計算の河道 


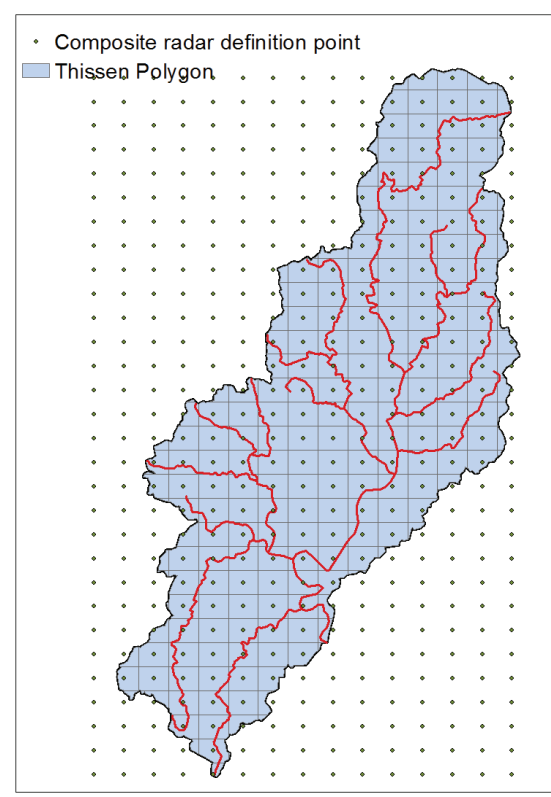

図-2 合成レーダ出力点及び佐用川流 域のティーセン分割図

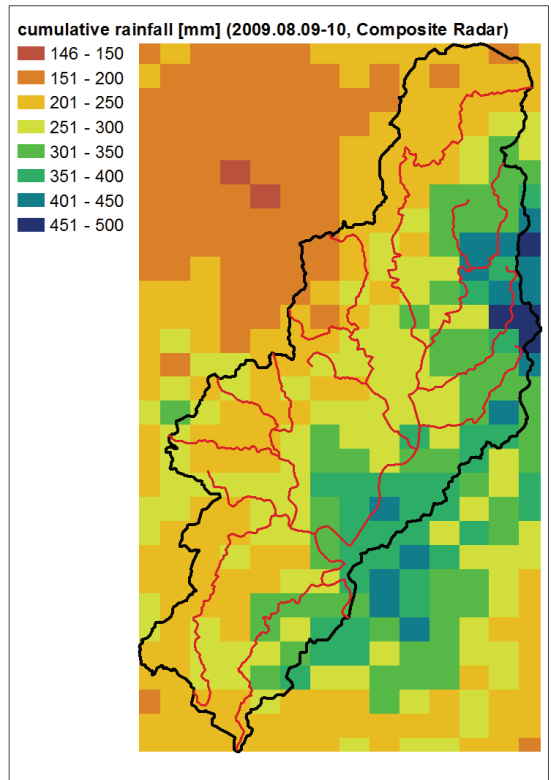

図-3 合成レーダ各出力点における2009 年8月9日0時〜10日23時の累積雨量

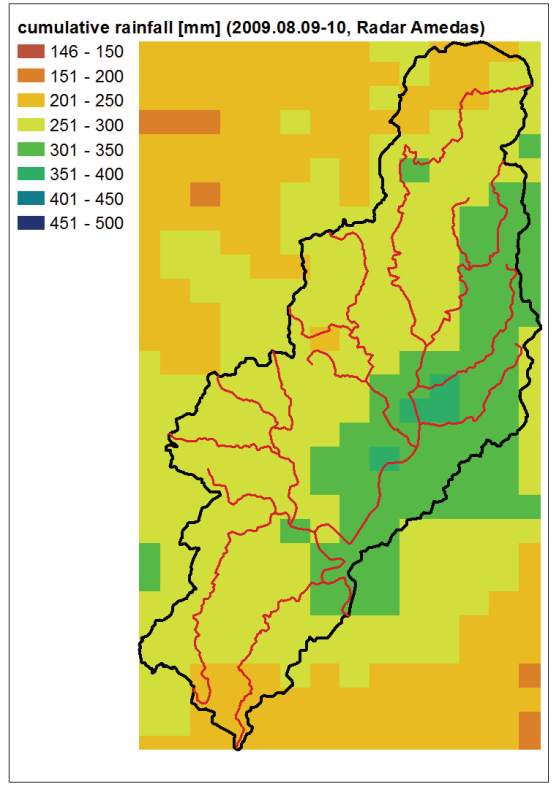

図-4 レーダ・アメダス解析雨量各 出力点における2009年8月9日0時〜 10日23時までの累積雨量
位置 $(\mathrm{k}, \mathrm{k}=0, . ., 2614)$ で越流公式に基づく単位幅流量×節点 間距離（60m）に相当する流量qが側方流入として河道 に流入する 。この側方流入は一次元河道の $60 \mathrm{~m}$ 間隔の 各節点の左右岸で存在する。 また，逆に河道流の水位 が堤防高さを超えた場合にも，河道位置(k)から堤内地 (i, j) 一越流公式により推定される流量が溢水する. 側 方流入出ともに完全越流ともぐり越流を区別する.

下流端境界条件は観測值を与え，上流端については 一定水深を与える.ここで採用した基礎方程式，数值 計算手法については例えば小林・寶9も参考にされたい.

この手法は汇濫解析手法を流域全体に拡張したとも 言えるし，分布型降雨流出モデルで一般に適用されて いるkinematic wave法を1次元・2次元不定流モデルで代 替したものともいえる. 森林については, 恩田ら ${ }^{10}$ など を参考に $25 \mathrm{~mm} / \mathrm{hr}$ の浸透能があり，それ以降表面流が発 生するとした. 本稿では表面流の支配方程式が物理法 則に基づいているため, 地中流を概念モデルや半物理 式で追跡することを避けた，森林土壌の流れのより具 体的な取り扱いについては今後の課題である.

一次元不定流計算については以下の連続式と，抵抗 則にManning公式を用いたSt.Venant式を適用する. 連続式:

$$
\frac{\partial A}{\partial t}+\frac{\partial Q}{\partial x}=q
$$

運動量方程式：

$$
\frac{1}{g} \frac{\partial u}{\partial t}+\frac{u}{g} \frac{\partial u}{\partial x}+\frac{\partial h}{\partial x}=s_{0}-\frac{n^{2} u|u|}{R^{4 / 3}}
$$

ここにAは河道での流水断面積， $Q$ は河道内流量， $q$ はx 方向の単位長さあたり横流入出量（流入が正）, $g$ は重
力加速度, $u=Q / A$ は断面平均流速, $s_{o}$ は水路床勾配, $n$ はマニングの粗度係数, Rは径深である. 数值計算には 特性曲線法を用いる.

堤内地の汇濫解析には2次元浅水流方程式を用いる. 連続式：

$$
\frac{\partial h}{\partial t}+\frac{\partial M}{\partial x}+\frac{\partial N}{\partial y}=Q_{\text {in/out }}
$$

運動量方程式：

$$
\begin{gathered}
\frac{\partial M}{\partial t}+\frac{\partial u M}{\partial x}+\frac{\partial v M}{\partial y}=-g h \frac{\partial H}{\partial x}-g n^{2} u \frac{\sqrt{u^{2}+v^{2}}}{h^{1 / 3}} \\
\frac{\partial N}{\partial t}+\frac{\partial u N}{\partial x}+\frac{\partial v N}{\partial y}=-g h \frac{\partial H}{\partial y}-g n^{2} v \frac{\sqrt{u^{2}+v^{2}}}{h^{1 / 3}}
\end{gathered}
$$

ここにhは水深, $M=u h, N=v h て ゙ M, N$ は流量フラックス, u, 梳それぞれx方向, y方向流速, $H$ は水位, $Q_{\text {inout }}$ は単 位面積当たりの2次元格子への流入出量である. $h, M, N$ を千鳥格子状に配置し (staggered grid), 時間方向差分に は陽的解法のLeap frog 法を用いる.

\section{4. 合成レ一ダ・レーダアメダスによる降雨解析}

2009年8月9日〜10日にかけての佐用川流域における 降雨の分析のために, 気象庁より提供されている合成 レーダ雨量, 及びレーダ・アメダス解析雨量を用いた ${ }^{11}$. 概要は次の通りである.

$1 \mathrm{~km} メ ッ シ ュ$ 全国合成レーダ : 気象庁が保有する全国 20台の気象レーダーで観測されたエコー強度（レー 


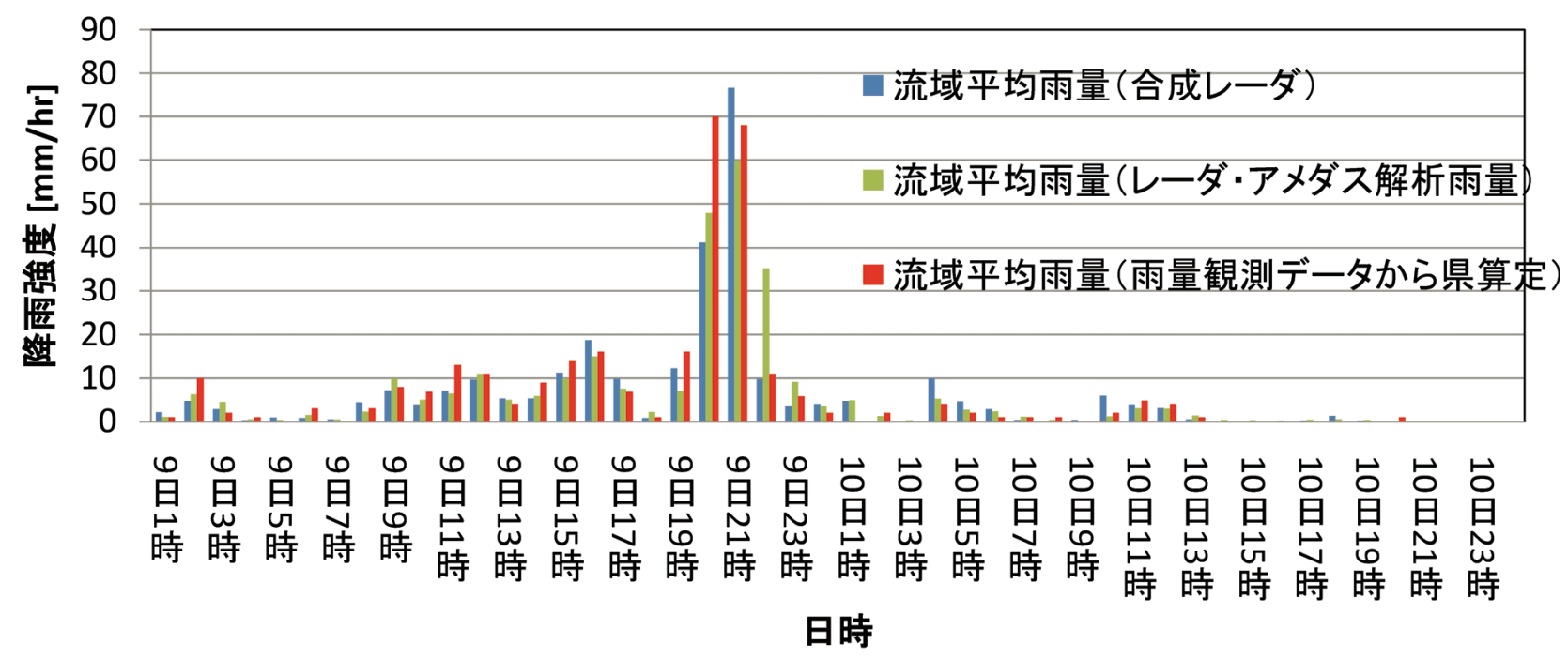

図-5 2009年8月9日〜10日の佐用川流域での流域平均雨量推定図

ダーで観測される換算降水強度）で 10分間隔で提供さ れている.

$1 \mathrm{~km}$ メシュレーダ・アメダス解析雨量 : 気象庁の保 有する気象レーダと地域気象観測（アメダス）データ を用いてメッシュで解析した 1 時間降水量であり，30分 間隔で提供されている。

図-2に合成レーダの出力点位置を佐用川流域に重ね 合わせた図を示す。同図には流域平均雨量を計算する 際のティーセン分割図も示している．まず合成レーダ を用いて，2009年8月9日0時〜10日23時までの2日間累 積雨量を各出力点で計算した結果を図-3に示す．佐用 川流域で2日間雨量450-500mmの降雨を示寸図中上部右 側地域から $150 \mathrm{~mm} / 2$ day以下の図中上部左側地域まで降 雨分布に幅があることがわかる。

他方，レーダ・アメダス解析雨量による2日間の累積 降雨量分布を図-4に示寸. 図-4のレーダ・アメダス解 析雨量による累積雨量を見ると, 図-3の合成レーダに よる累積雨量に比較して，全体に降雨強度差が縮まり， 最高2日間累積雨量の值も減少しているのがわかる.

図-5は合成レーダ及びレーダ・アメダス解析雨量に より算定した流域平均雨量, 兵庫県が算定した地上観 測雨量による流域平均雨量である. 図-5を見ると算定 された流域平均雨量值には幅があるのがわかる。例え ば，降雨が最高值を記録した9日21時においては，合成 レーダによる流域平均雨量が最大で, その後, 地上雨 量観測計による流域平均雨量, 最も小さいものがレー ダ・アメダスによる流域平均雨量となる. 他方20時に おいては，最大值が地上観測雨量による流域平均雨量 で, 次がレーダ・アメダスによる流域平均雨量, 最後 が合成レーダによる流域平均雨量となる.

レーダ・アメダス解析雨量は合成レーダの值をアメ ダス（地上観測值）により補正したものである.した がって，地上観測值が真值であるという立場に立って， 一般にはレーダ・アメダス解析雨量の方が合成レーダ
よりも信頼性のあるデータであると考えられている. 他方，合成レーダは出力間隔が短いため防災用に有効 であると考えられている，実際今回の流域平均雨量の 20〜21時の值を見ると，合成レーダの值がアメダスに より補正されて, レーダ・アメダス解析雨量の值に なっている様子は見て取れる、レーダ・アメダス解析 雨量の質の評価については，例えば参考文献 ${ }^{12}$ を参考に されたい. 本稿では，以降，レーダ・アメダス解析雨 量が降雨の空間分布を考慮することができ, かつ信頼 性が高いと考えて，洪水計算を実施した。

\section{5. 浸水深計算結果}

図-6は浸水実績図，図-7はレーダ・アメダス解析雨 量を用いて空間分布を考慮し計算した最大浸水深の流 域全体図，浸水実績図近辺を拡大したのが図-8である. まず，図-7を見ると，本稿のモデルでは標高データ により生じる山地部の窪地の処理を行っていないため, 流域全域において各窪地に水がたまっている様子が見 て取れる.

次に図-7の実績図近辺を拡大した図-8と図-6の浸水 実績図を比較すると良く一致しているのがわかる。た だし，細部には差異が見て取れる。こうした差異は基 本的には標高データの解像度・精度，及び河道の表現 形式にもう少し工夫が必要なことなどを示唆している と考えている. 本稿では標高データに国土地理院の数 值地図 $50 \mathrm{~m}$ ッシュデータ（標高）を用いたが，この データの精度は7.2mとある。これにより微地形が十分 に再現されていないことが推測される．また，河道幅 が二次元モデル解像度より高い場合などは河道の表現 形式に修正が必要になると思われる.

しかしながら，レーダ・アメダス解析雨量を用いた シミュレーションによる佐用町総合庁舎の最大浸水深 


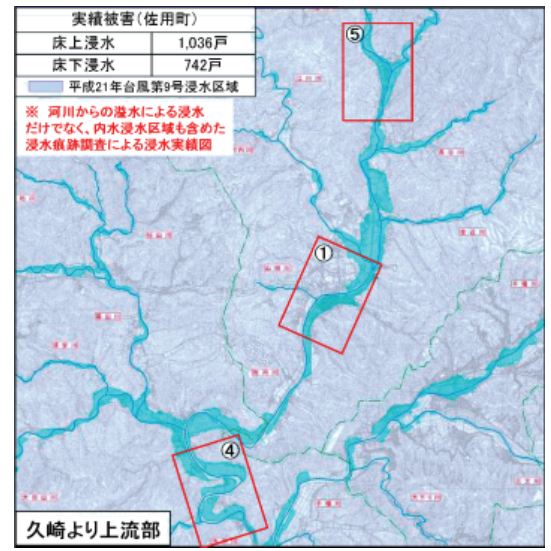

図-6 浸水実績図 ${ }^{1)}$

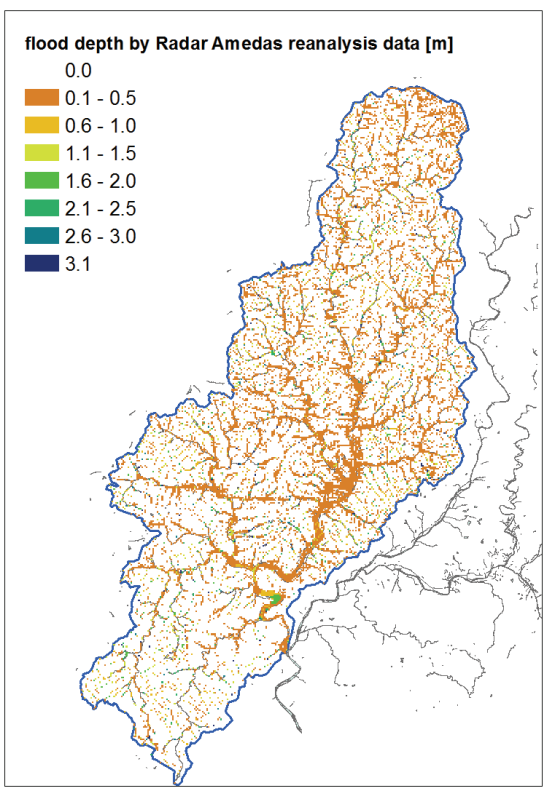

図-7 レーダ・アメダス解析雨量によ る浸水深計算結果

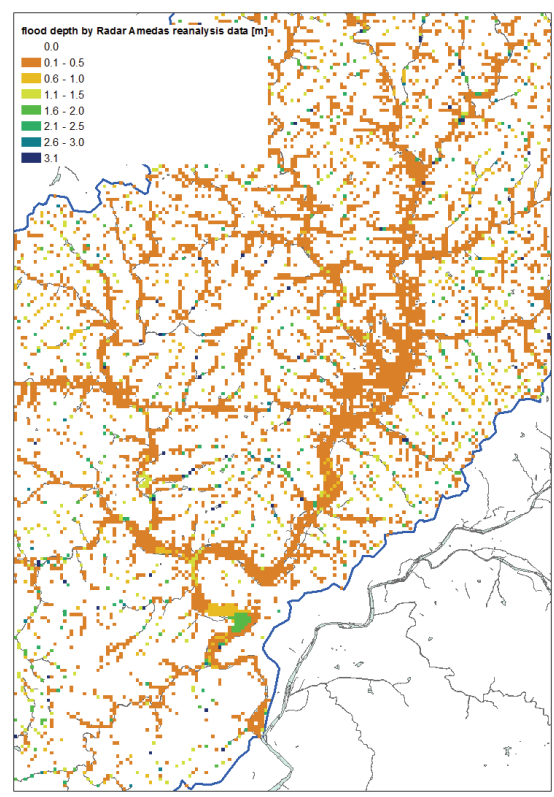

図-8 図-7拡大図（浸水実績図範囲）

は $1.16 \mathrm{~m}$ となり，兵庫県台風9号追加資料 $\left.{ }^{13}\right)$ とる総合庁 舎の実績浸水深は $1 \mathrm{~m}$ 程度であったとあるので，シミュ レーションの全体的な再現性は良い.

\section{6. 家屋・農作物経済被害推定}

経済被害推定はGISを用いて実施した。兵庫県佐用町 については家屋一棟一棟を詳細に再現したベクトル型 のポリゴンデータが存在するのでこれを経済被害推定 の基礎データとして用いる. 他方, 農地一区画一区画 を詳細に再現したベクトル型データは佐用川流域につ いては存在しないので, 国土数值情報による $100 \mathrm{~m}$ 解像 度の土地利用データから農地を選択抽出して基礎デー タとして用いた。 以下の推定法の詳細については小林

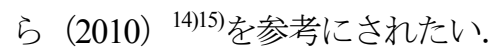

概略の手順は以下のようである. 最初に内水・外水

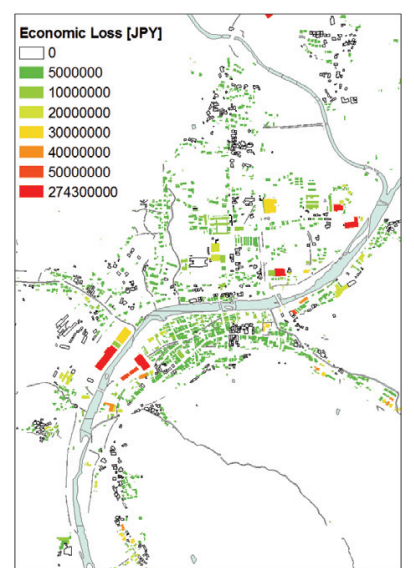

図-9 被害推定モデルによる 建造物被害額分布図

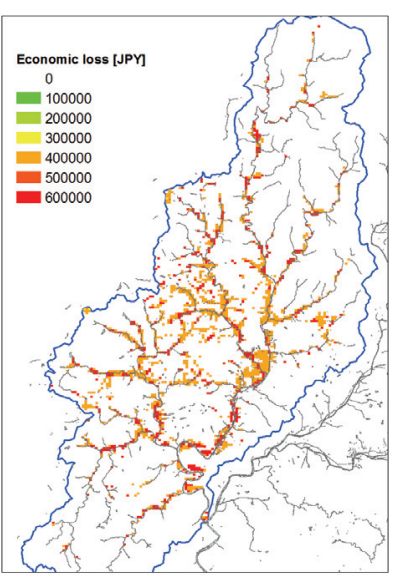

図-10 被害推定モデルによる 農地被害額分布図
氾濫解析を実施し，これにより計算された浸水深をグ リッドセルで出力する. 次にグリッドセル浸水深を各 家屋や農地のポリゴンデータに属性情報として割り当 てる. 複数のグリッドセルが一つのポリゴンと重叔合 う場合, 複数の水深の最大浸水深を取る. その後, 各 家屋や農地の浸水深に応じたいわゆる被害率（家屋・ 農地の評価額が受ける被害の割合）を治水経済調査マ ニュアルの統計值 ${ }^{16}$ 用いて計算する．この手続きによ り各家屋あるいは農地毎に被害率が割り当てられる。 その後, 家屋については「面積当たり家屋評価額 $\times$ 面積 ×被害率」により被害額を推定する．農地については 「面積当たりの作物収量 $\times$ 単位重さあたり作物価格×面 積×被害率」により農地作物被害額を推定する。ここで は ${ }^{16)}$ ，兵庫県の面積当たり評洒額を 150600 円，面積当た り作物収量を $0.514 \mathrm{~kg} / \mathrm{m}^{2}$, 単位重さあたり作物価格を 289円 $/ \mathrm{kg}$ とした.

この手続きにより推定された佐用町付近の建造物被 害額分布を図-9に示寸．500万円以下の被害が多くの建 造物について推定されているのがわかる.この手法に より推定された佐用川流域の総被害額は最低最大浸水 深 $(1 \mathrm{~cm})$ を含めると242億円，これを除くと204億円と なった．兵庫県による住宅の見込み被害額が185億円で あるから，ある程度の精度で被害推定ができていると 考えられる。 なお，ここでの経済被害推定では，流域 に降った雨による各地点の最大浸水深を被害推定の基 礎データとして用いるため, 雨が降ればかならず多少 の浸水は発生し，ここから最大浸水深を取れば流域の どの地点においても被害が発生することになってしま う。この最低の最大浸水深が、本稿のモデル設定では $1 \mathrm{~cm}$ であるた, この最低の最大浸水深は被害額計算か ら取り除くという計算結果を併記することとする。一 方農地作物の推定被害額分布を図-10に示寸. 各農地で 
40～60万円程度の被害が推定されている. この推定モ デルによると農地の総被害額は7億6800万円となった. 他方, 佐用町による農作物被害報告額は2億 450 万円で ある、農地については $100 \mathrm{~m}$ 解像度の土地利用データを 用いたので, 農地面積が常に $100 \mathrm{~m} \times 100 \mathrm{~m}$ になり実際よ り過大で被害額も過大に評価していると考えられる. なお，田畑についても最低最大浸水深 $1 \mathrm{~cm}$ 以下を除くと 被害額は7億4000万円となった. これにより推定モデル は被害額を概算する能力は十分に有していると考える.

\section{7. 結論}

本稿では最初に2009年8月9日〜 10日に発生した佐用 町における豪雨災害の流出・浸水現象をシミュレー ションにより再現することを試みた。 また計算浸水深 に基づいて家屋・農地の経済被害を推定し，その総額 を実際に佐用町や兵庫県により報告されている見込み 被害と比較することで, 経済被害推定モデルの精度を 確認した.

流出・浸水現象の再現に当たっては, 統合型の降雨 流出・洪水汇濫追跡モデルを構築した. これは従来の, 流出モデルにより河道流量を推定し，これを境界条件 として洪水汇濫計算を実施する手法に比較しても幾つ か利点がある．例えば，山腹斜面から平地一の流入流 量を考慮した汇濫追跡が可能であること, 汇濫原を事 前に設定する必要がないことなどがあげられる．流域 全体を一体型でモデル化できることから取り扱いが容 易であることなども言える。，一方で，計算負荷が高い ことから一出水に対しては単一PCでも取り扱いが可能 であるが，長期の流出現象や水循環をモデリングした い場合には, 並列化などの作業が必要となる. 本稿で はこの統合型モデリングにより佐用町の浸水現象を良 く再現できたと考えている.

経済被害推定モデルについても，自治体による経済 被害報告額も基本的には精度の高い推定值であること を考えると，概算值を提供するには良い精度を持って いると考えられる.

今後はこれらの八ザード，経済リスクモデルの更な るキャリブレーションを実施して, 推定精度を高める 所存である.

謝辞 : 土木学会調查団への参加を通じて, 兵庫県及び 佐用町にはデータ・資料提供など多大なご助力をいた だいた。 また本研究は文部科学省グローバルCOEプロ グラム「極端気象と適応社会の生存科学 (PI : 寶 馨）」の支援を受けた. 経済被害推定モデルの開発に 当たっては河川情報センターより助成金を受けた。こ こに記して心より感謝いたします。

\section{参考文献}

1) 佐用町 : 台風第9号災害検証報告書,

http://www.town.sayo.lg.jp/kakuka/saigaifukkotaisaku/kensyouiink ai/kensyouhoukokusyo.pdf, 2010

2) 兵庫県災害復興室 : 平成 21 年台風第 9 号災害の復旧・復興計 画, http://web.pref.hyogo.jp/contents/000143772.pdf, 2009

3) 宇野 宏司・中野 晋・梅岡 秀博 - 渡辺一也: 平成21年台 風9号による洪水汇濫特性一兵庫県佐用町久崎地区を例とし て一, 土木学会水工学論文集第54巻, pp. 865-970, 2010

4) 宇野 宏司・中野 晋・久米賢治 : 2009年8月佐用町豪雨災害 にみるソフト防災対策の有効性とその限界，河川技術論文 集第16巻, pp. 489-494, 2010

5) 国土交通省 : 国土数值情報ダウンロードサービス, http://nlftp.mlit.go.jp/ksj/, 2009

6) 井上和也・戸田圭一・前田修: 河川網が発達した領域での 汇濫解析法とそのメコンデルタでの適用, 土木学会水工学論 文集第44巻，pp. 485-490，2000

7) 川池健司 - 井上和也 - 戸田圭一 ・ 野口正人 : 低平地河川流 域での豪雨による都市汇濫解析, 土木学会論文集, No.751/II67,pp.57-68, 2005.

8) 市川温・村上将道・立川康人・椎葉充晴 : 流域地形の新た な数理表現形式に基づく流域流出系シミュレーションシステ ムの開発，土木学会論文集，No. 691/II-57,pp. 43-52， 2001

9) 小林健一郎・寶 馨 : 雨域の移動が流域の降雨流出・洪水 汇濫過程に及ぼす影響, 土木学会水工学論文集第 53 巻, pp. $841-846,2000$

10）恩田裕一・辻村真貴 - 野々田稔郎 - 竹中千里 : 荒廃したヒ ノキ人工林における浸透能測定法の検討, 水文・水資源学会 誌18(6), pp. 688-694, 2005

11) 熟見哲也：レーダー・アメダス解析雨量の利用例, http://sumisumi.cocolog-nifty.com/sumisumi/files/Rader-AME.pdf, 2009

12) Kamiguchi, K. et al.: Development of APHRO_JP, the first Japanese high-resolution daily precipitation product for more than 100 years, Hydrological Research Letters, 4, pp. 60-64, 2010

13）佐用町：台風第9号災害にかかる追加資料について, http://www.town.sayo.lg.jp/kakuka/saigaifukkotaisaku/kensyouiinkai /dai2kai/3 tsuikashiryou.pdf, 2009

14）小林健一郎・寶 馨・中北英一 : 全球気候モデル出力と洪 水及び経済被害推定モデルを用いた中小河川の水害リスクの 将来変動に関する研究，河川技術論文集第16巻, pp.495-500, 2010

15) Kobayashi, K., Takara, K., Funada, M. and Takeuchi, Y.: Development of a Framework for the Flood Economic Risk Assessment Using Vector GIS Data, Journal of Disaster Research, Vol. 5 No.6, pp. 657-665, 2010

16）国土交通省：治水経済調査マニュアル（平成17年度版）, http:/www.gsi.go.jp/chizujoho/chizujoho40004.html\#09, 2010

(2010.9.30受付) 